\title{
Asiantuntijaorganisaation täytyy selvittää suhteensa tietotekniikkaan
}

\section{Tietotekniikan tulo työpaikoille on merkinnyt ja merkitsee jatkossakin suurta muutosta työnteossa. Inhimillistä työtä on vasta teollistumisen alkaessa viime vuosisadalla alettu ohjata niihin uomilinsa, joissa tuotantoteknilkka nykyään on. Tuotannollisiin murroksiin on aina kuulunut työtapojen uudelleenjärjestelyjä, organisaatiofilosofisten lähtökohtien uudelleenarviointia ja johtamismenetelmien tarkistamista. Koulutus on ollut jokaisessa murroksessa keskeisessä asemassa, sillä sen avulla on siirretty osaamista eteenpäin ja kehitetty valmiuksia suhtautua työhön.}

Seuraavassa olen arvioinut joitakin tietotekniikan käyttöön liittyviä näkökohtia lähinnä Suomessa julkaistujen kirjoitusten pohjalta. Useimmilla työpaikoilla tietotekniikka on otettu käyttöön jo 1980-luvun puolesta välistä lähtien, mutta se ei olekaan tuonut paperittomia toimistoja eikä edes välttämättä lisännyt työn tuottavuutta. Koneet on nyt hankittu, niiden käytön ja koulutuksen osalta on tilanne vielä vähän niin ja näin.

\section{Stressaava \\ tietotekniikka}

Perusvirhe on tehty, tehdään ja tullaan edelleen tekemään siinä, että suorittavaa henkilökuntaa, sitä työyhteisön osaa, joka itse asiassa te- kee työt, ei tietotekniikan käyttöönoton yhteydessä kuunnella. Muutosten käytännön suunnittelu ja toteutus ratkaistaan osana työpaikkojen olemassaolevia valtasuhteita (Korvajärvi-Järvinen-Kinnunen 1990, 161-162). Ne, jotka eivät [jostain syytä] oikein tunne työtä, tekevät päätökset uuden tekniikan hankkimisesta ja käyttötavoista.

"Silloinhan ne tyypit mainosti, että käyttömahdollisuudet ovat rajattomat. Ja me istuttiin tässä ja opeteltiin niitä nappuloita. Ei oo kyllä minkäänlaista käsitystä siitä, mitkä ovat ne rajattomat käyttömahdollisuudet tässä hienossa systeemissä, joka meillä on. Tarttis olla vähän laajempaa käsitystä."

\section{(Kallioniemi 1985, 65.)}

Graid Brod, tietokoneiden mukanaan tuomien muutoksien tarkkailuun erikoistunut psykoterapeutti, julkaisi vuonna 1984 raflaavan teoksen "Technostress - The Human Cost of the Computer Revolution", joka suomennettiin 1986 nimellä "Teknostressi - Hinta, jonka ihminen maksaa tietokonevallankumouksesta". Kirjan ote on varsin amerikkalainen siinä mielessä, että tietotekniikan tuomat ongelmat yksinkertaistetaan ja perusnäkemys on vahvasti pragmaattinen. Brod luettelee kuitenkin muutamia tavallisia virheitä, joita organisaatioiden johtajat säännöllisesti tekevät, kun tietotekniikkaa käytetään organisaatiossa. Tässä muutamia otteita:

1. He luulevat, että tietokoneet voivat ratkaista ongelmia, jotka pohjimmiltaan liittyvät henkilökuntaa koskeviin kysymyksiin.

2. He olettavat, että kaikki työntekijät pystyvät oppimaan teknologian yhtä nopeasti. 
3. He salaavat uudelleenkouluttamista ja erottamista koskevan politiikkansa antaen siten aihetta huhuille.

4. He delegoivat koko vastuun uuden tietokonejärjestelmän käyttöönotosta alemman asteen johtajille.

5. He pienentävät henkilökunnan kouluttamiseen tarvittavan rahamäärän aivan minimiin.

\section{(Brod 1986, 52-53.)}

Toimistotyötä on tietokoneistettu voimakkaasti tavoitteena rationaalisempi ja tehokkaampi toimisto. Toimistotyöntekijöiden työnkuvat ovat kuitenkin pikemminkin irronneet työkokonaisuudesta kuin integroituneet siihen entistä paremmin. Tästä on seurauksena, että yksilön kannalta organisaation tavoitteet ja työkokonaisuudet - reflektiivisyyden perusedellytykset - ovat monesti hämärtyneet, kun työ on muuttunut entistä rutiininomaisemmaksi. Tyypillisesti ammattitaitotarve vähenee toimistotyötä automatisoitaessa, ihmisten välinen viestintä ja tehtävien koordinointi vähenee ja työ siirtyy yhä enemmän pelkälle työn suorittamisen alueelle. Tiedon arvioinnin tarve ja merkitys vähenevät, samoin kuin ajattelun tarve.

"Työskentelen nyt painamalla nappuloita. Meitä kaikkia on kurssitettu, jotta tiedämme, mitä näppäintä on painettava minkin tiedon esiin saamiseksi."

"Kun on painanut ENTER-näppäintä, ei toimintaa voi millään tarkistaa tai pysäyttää. Se on mennyt sisään, ja se on kammottavaa. Joskus sitä vain painelee nappuloita. Sitten se juttu seisoo naamasi edessä kymmenen sekunnin ajan ja äkkiä huomaat: 'Voi ei, mitä minä nyt olen tehnyt?' Mutta silloin se on liian myöhäistä."

\footnotetext{
"Tietokonejärjestelmä viestittää minulle, se sanoo: 'Sinun ei tarvitse olla kaikesta selvillä.' Tosiasia on, että teemme paljon virheitä. Ja mitä vähemmän ihmisiä rohkaistaan tietämään asioita, sitä enemmän näitä virheitä löytyy."
}

Edellä olevat lainaukset ovat Harvard Business Scoolin professorin Shoshana Zuboffin kirjas- ta Viisaan koneen aikakausi. (Zuboff 1990, 155-163.) Zuboff haastatteli yritysten eri hierarkioilla toimivia henkilöitä usean vuoden ajan tutkimustaan varten. Tutkimus tehtiin Yhdysvalloissa: vakuutusyhtiössä, puunjalostustehtaassa ja pankissa. Mukana olivat siis perinteinen raskaan teollisuuden laitos että ns. tietoammattien alojen edustajia. Tietotekniikan ilmiöt eli laitteistot, ohjelmistot ja tietotekniikan käyttötavat ovat tulleet Suomeen yleensä noin kahden vuoden viiveellä Yhdysvalloista; ei ole siis sinänsä syytä epäillä, etteivätkö Zuboffin johtopäätökset olisi relevantteja myös Suomessa. Tätä väitettä tukevat lähes kaikki Suomessa tehdyt tietotekniikan käyttöönottoa selvitelleet tutkimukset, ikävä kyllä.

Puunjalostuslaitoksen automaation edetessä työntekijät menettivät aikaisempaa asiantuntijuuttaan. Työ oli ennen vaatinut sellunvalmistuksen prosessin tuntemista, ja hankittu asiantuntijuus perustui paitsi kognitiivisiin, myös affektiivisiin ja jopa fyysisiin valmiuksiin (sellumassan haju, miltä jokin prosessiliemi tuntui sormien välissä) (Zuboff 1990, 78-80). Kaikkiaan ennen tietotekniikan käyttöönottoa asiantuntemuksen luonne oli kokemuksellisempaa kuin näyttöpäätteiden tultua valvomoon, jolloin kokemuksellista tarkkaavaisuutta piti yrittää kehittää kognitiivisen tarkkaavaisuuden suuntaan. Kaikki se, mihin työntekijöillä oli ollut aistimellinen tuntuma ja sen pohjalta saavutettu asiantuntijuus, siirrettiin näyttöpäätteiden jakamaksi informaatioksi, jolla ei välttämättä ollut työntekijöille enää merkityssisältöä.

\section{Kognitivistisesta autuudesta asiantuntevaan oppimiseen}

Väite, että kauan jotakin työtä tehnyt on asiantuntija työssään, on triviaali ja yleinen. Valitettavasti se on väärä, jos asiantuntijuus käsitetään kyvyksi hallita aktiivisesti oman työprosessinsa tavoitteita ja muutoksia. Reflektiivistä suhtautumista omaan työhön pidetään kansainvälisessä työelämän kehittämisen keskustelussa asiantuntijuuden kompetenssin keskeisenä määreenä (Eteläpelto 1992, 11). Kasvatustieteessä käsitteillä "kognitiiviset taidot" tai "metakognitiot" tarkoitetaan yleensä yksilön taitoja ratkais- 
ta tiedollisia tehtäviä, oppia uusia asioita ja muistaa niitä; reflektiivisyydellä tarkoitetaan laajempaa kokonaisuutta, johon kuuluu oleellisesti kriittinen tietoisuus koko toimintakontekstista.

Yrjö Engeström on tuonut aikuiskasvatukseen ehkä tunnetuimman, alkusoluun ja orientaatioperustaan perustuvan koulutusmallinsa, jossa lähdetään kognitiivisista lähtökohdista kehittelemään kuhunkin tilanteeseen sopivimman tuntuista opetusmallia (Engeström 1988, 76-80). Myöhemmässä työssään Engeström painottaa voimakkaammin työyhteisön kokonaisvaltaiseen kehittämiseen ja eri työrutiinien synergian löytämiseen konkreettisessa toiminnassa (Engeström 1990, 69-106).

Reflektiivisyyden edistäminen merkitsee omakohtaisen vastuullisen suhtautumisen korostamista, itsearviointia edistävän palautteen saamista, oman työn tutkivaa kehittämistä ja työnohjauksen olemassaoloa. Reflektio voidaan ymmärtää oppimisen vaiheeksi, jossa kokemuksia tarkastellaan tietoisella tasolla, siis itse koettua yritetään ymmärtää ja pukea sanoiksi. (Eteläpelto 1992, 14-15.)

Reflektiivisyyden käsitettä voi pitää monessa suhteessa kognitiivisen, ongelmanratkaisuorientoituneen, oppimisen laajennuksena. Mezirovin mukaan reflektiivisyyden käsitteeseen kuuluu komponentteja, joita kognitiivisessa oppimis-opetus -syklissä ei ole (Mezirow 1991, 103-110). Reflektiivisyyteen kuuluu tietoisuus havainnoista, ajattelusta, toiminnasta sekä näihin liittyvistä tottumuksista. Jatkuva oppiminen on riippuvaista siitä, kuinka hyvin oppija on tietoinen siitä, mitä hän on oppinut, miten hän on oppinut ja mihin oppiminen johtaa; johtaako se esimerkiksi muutoksiin työprosesseissa.

Toimistotyön automatisoinnissa organisaatiossa olleen työnjaon on ajateltu pysyvän entisellään: työnjaon ja henkilöiden tehtäväkuvien muuttamisen ei ole ajateltu riippuvan mitenkään tietotekniikasta. Taustalla väikkyy tayloristinen malli ositetusta työstä ja valtakysymys siitä, että "kaikki jatkuu ennallaan" (Korvajärvi 1990, 76-79). Eli joka paikassa on hyvää tahtoa, mutta mitään muutoksia ei tehdä. Organisaation tehottomuus on yleensä johtavan henkilökun- nan korvien välissä, ei tietotekniikassa. Suomalaisella työntekijällä näyttää olevan lisäksi erityinen kansallinen eetos mukautua kaikenlaisiin organisationaalisiin älyttömyyksiin, myöskin tietotekniikan käyttöönotossa: "hommat tehdään, vaikka henki menisi" (Kortteinen 1992, 253-294).

Mikäli asiantuntijuudella tarkoitetaan siis tässä yhteydessä oman työnsä osaamista, niin edellisten määrittelyjen mukaisesti voidaan vaatia, että työtä tekevä henkilö tietää, mitä hän on tekemässä, miten ja miksi, ja voi myöskin tarvittaessa vaikuttaa siihen. Tietotekniikan tulo työpaikoille ei suinkaan ole merkinnyt näiden asioiden edistymistä. Pikemminkin "tietoammattien" erityisluonteen korostaminen voi helposti palvella tayloristisen mallin siirtämistä sellaisenaan nykyaikaan: ennen tietokoneitakin olivat erikseen työn suunnittelijat ja johtajat, erikseen työtä suorittava henkilöstö (Vuorinen 1991, 20). Johtoa tämänkaltainen suora tayloristisen mallin siirto tietenkin palvelee, etenkin nykyään uhattua keskijohtoa, mutta se ei välttämättä johda järkevään tulokseen.

Käytännössä asiantuntijamainen, reflektiivinen, suhtautuminen tietotekniikan koulutuksessa organisaatioissa lienee vain kaukainen haave. Reflektiivisen näkemyksen koulutusnäkemyksen soveltaminen organisaation henkilökunnan tietotekniikan koulutuksessa edellyttää nimittäin aina johdon tietoisuutta siitä, mitkä ovat organisaation pitkän tähtäimen päämäärät ja minkälaisia prosesseja näitä päämääriä varten on organisaatiossa käynnissä. Lisäksi edellytetään kommunikatiivisuuden vaatimuksen toteuttamisesta, koska asiantuntijayhteisö on yleensä hyvin kommunikatiivinen. Yleensä tiedon kulku ylhäältä alas ja päinvastoin toteutuu jollakin tasolla, mutta aiheuttavatko informaatiovirrat sitten jotain todellisia muutoksia työprosesseissa?

\section{Tietotekniikka \\ ja tulosvastuu}

Tietotekniikkaa käyttävillä työpaikoilla yli puolet ihmisistä on tulosvalvonnan piirissä. Tällaisilla työpaikoilla myös työyhteisön ongelmat 
ovat yleisiä. Timo Kolu on tutkimuksessaan todennut, että sellaisilla työpaikoilla, joilla tehdään töitä tulosvastuulla, 72 prosenttia työntekijöistä on sitä mieltä, että kilpailuhenki on työyhteisössä lisääntynyt. Sama prosenttiosuus vastaajista oli sitä mieltä, että työntekijöiden keskinäiset ristiriidat ovat lisääntyneet ja 74 prosenttia katsoi esimiesten ja työntekijöiden ristiriitojen lisääntyneen. (Tietoviikko 27.5.1992, 5.)

Työyhteisöissä on havaittu konflikteja ja kilpailua epävirallisesta vallasta: asiantuntijat sekä erilaisten kehittämishankkeiden vetäjät näyttävät käyttävän tuota epävirallista valtaa (Vepsäläinen 1990, 10).

Tietotekniikan käyttö ja tulosvastuu ovat kaksi eri asiaa. Kumpaankin liittyy kuitenkin suuria koulutuksellisia - sekä johdon että suorittavan portaan osalta - haasteita. Kun nämä kaksi sellaisenaan vaikeaa asiaa yhdistetään, niin kuin varsinkin julkishallinnossa on viime vuosina jouduttu tekemään, niin vaikeudet kasvavat eksponentiaalisesti. Vaikeuksista seuraa työstressiä, joka voi ilmetä työntekijöiden psyykkisissä toiminnoissa, käyttäytymisessä ja elimistön toiminnassa (Rajala 1989, 91). Työntekijä voi ärtyä, pohdiskella asioita loputtomasti ja ahdistua, toisaalta stressiä voi yrittää välttää pakenemalla vastuuta ja syyllistämällä muita (Rajala 1989, 94). Ongelmat koskevat sekä suorittavan työn tekijöitä että johtoa.

\section{Tietotekniikan \\ koulutusvaatimuksia}

Tietotekniikan koulutuksen vaatimukset voi karkeasti jakaa kahteen luokkaan. Ensimmäisenä voi pitää niitä pedagogisia erityisvaatimuksia, joita valmisohjelmakoulutukseen liittyy - suurin osa organisaatioiden tietotekniikan koulutuksesta on valmisohjelmakoulutusta. Toisena suurena luokkana voi pitää vaatimuksia, joita tietotekniikan tehokas käyttö asettaa organisaatiolle.

Tietotekniikan koulutuksessa on ensinnäkin määriteltävä se tavoitetaso, johon pyritään. Karkeaan tavoiteharkintaan voi käyttää valmisohjelmakoulutukseen sovellettavaa Biggsin ja Collinsin tavoitetaksonomiaa, jossa alimmalla tasol- la (taso 1) on esistrukturaalinen näkemys opittavasta asiasta. Korkeimmalla tasolla (taso 5) oppijalla on laaja-alainen teoreettinen näkemys opittavasta asiasta. (Biggs ja Collins 1982, 24-25).

Tietotekniikan opetukseen (ja myös koulutustulosten arviointiin) sovellettuna taksonomia voisi saada seuraavan sisällön:

1. Esistrukturaalinen näkemys opittavasta asiasta.

Oppija pyrkii jotain uutta asiaa opetettaessa vaikkapa harjoittelemaa näppäimistön käyttöä tai kääntämään muulla tavoin ajatuksensa pois asiasta.

2. Yksistrukturaalinen näkemys opittavasta. Laajempaa tehtävää opetettaessa oppija "juuttuu" jonkin yksittäisen käskyn tai komennon harjoitteluun.

\section{Multistrukturaalinen näkemys.}

Oppija muistaa yksittäisiä käskyjä ja komentoja, joita kokeilee irrallaan toisistaan.

4. Näkemys, jossa opittavan ilmiön osia on jo suhteutettu.

Oppija pystyy näkemään ohjelmiston käytön verkkona, jossa yksittäiset käskyt ja toimenpiteet ovat hierarkisoituneita ohjelman sisäisen rakenteen edellyttämällä tavalla.

5. Laaja-alainen, teoreettinen näkemys.

Oppija pystyy käyttämään ohjelmaa hyväkseen työssään joustavasti ja haluamallaan tavalla. Mikäli työ muuttuu, niin oppija kykenee itsenäisesti muuttamaan ohjelman käyttöä uuteen ympäristöön sopivaksi.

\section{(Stachon 1991, 154-156).}

Turha edes sanoa, että teoreettisen näkemyksen tasolle ei yleensä päästä. Ensinnäkin, sinne ei yleensä edes pyritä koulutusta suunniteltaessa ja toiseksi, tavoite olisi didaktisesti vaikea saavuttaa. Uskallan väittää, että tavoitetasoa ei edes ajatella koulutusta suunniteltaessa, ajatellaan vain päätekäyttäytymisen muotoja.

Organisaation kannalta koulutuksen vaatimukset ovat vaikeammin määriteltäviä. Joka ta- 
pauksessa tietotekniikan laajamittainen käyttö (esimerkiksi paikallisverkkoympäristössä) edellyttää tavoitteiden määrittelyä. Halutaanko työntekijöille kehittynyt kirjoituskone käyttöön? Vai halutaanko kehittää sisäisiä informaatiojärjestelmiä ja parantaa tiedonkulkua? Tämäntyyppiset kysymykset on ratkaistava, ennenkuin organisaatiota voidaan järjestelmällisellä koulutuksella alkaa kehittää.

Behavioristis-tayloristisesta koulutus- ja työnjohtomallista kiinnipitäminen edesauttaa varmasti status quon voimassapysymistä ja organisaatio toimii stabiilisti. Klassinen tuotantotekijöiden jako raaka-aineisiin, pääomaan ja työhön on koko yhteiskunnan tasolla jatkuvasti painottunut työn parempaan hyväksikäyttöön: erityisesti tämä pätee ns. tietoammatteihin, aloille, joilla pääoman tai fysikaalisen raaka-aineen tarve ei ole tuloksen kannalta merkittävä. Kilpailuetua voidaan pitkällä tähtäimellä ylläpitää vain tasokkaalla koulutuksella. Lyhyen tähtäimen henkilöstökoulutus on tietotekniikasta puhuttaessa nähdäkseni Pyrrhoksen voitto: välittömät tavoitteet saavutetaan, mutta strateginen kilpailuetu menetetään vähitellen.

\section{LÄHTEET}

Biggs, J. \& Collins, K. 1982. Evaluating the Quality of Learning: the SOLO Taxonomy. New York. Academic Press.

Brod, G. 1986. Teknostressi - Hinta, jonka inminen maksaa tietokonevallankumouksesta. Alkuteos "Technostress - The Human Cost of the Computer Revolution". Helsinki. Otava.

Engeström, Y. 1988. Perustietoa opetuksesta 2.-4. painos. Valtion painatuskeskus.

Engeström Y. 1990. Learning, Working and Imaging twelve studies in activity theory. Jyväskylä. Orienta-Konsultit Oy.

Eteläpelto, A. 1992. Reflektiivisyys ja itsetuntemus asiantuntijuuden kehittymisessä. Teoksessa Kohti uutta opettajuutta. Jyväskylän ammatillisen opettajakorkeakoulun julkaisuja 3.

Kallioniemi, E. 1985. Työyhteisöön tuli tietojärjestelmä. Yhteiskuntatieteiden tutkimuslaitos D 77 / 1985. Tampere. Tampereen yliopisto.

Kortteinen, M. 1992. Kunnian kenttä - suomalainen palk- katyö kulttuurisena muotona. Hämeenlinna. Karișto Oy. Korvajärvi P. 1990. Toimistotyöntekijän yhteisöt ja muitoksen hallinta. Työelämän tutkimuslaitoksen julkaisuja T6/1990. Tampere. Tampereen yliopisto.

Korvajärvi P., Järvinen Riitta, Kinnunen Merja 1990. Muutokset kiireen keskellä. Työelämän tutkimuskeskuksen julkaisuja T7/1990. Tampere. Tampereen yliopisto.

Mezirow, J. 1991. Transformative dimensions of adult learning. The Jossey-Bass Higher and Adult Education Series. San Francisco, California. Jossey-Bass Itd.

Rajala, T. 1989. Työstressi kunnallishallinnossa - teoriatarkastelu. Lisensiaattityö. Tampereen yliopiston kunnallistieteiden laitos, julkaisusarja 3/1989. Tampere.

Tampereen yliopisto.

Stachon, K. 1991. Valmisohjelmakoulutuksen orientaatioperusta - nakökulmia orientaatioperustan löytämisen ongelmiin. Teoksessa Jatkuva koulutus ja elinikäinen oppiminen, toim. Raivola Reijo, Ropo Eero. Julkaisusarja A: tutkimusraportti N:o 49/1991. Tampere. Tampereen yliopisto.

Tietoviikko 27.5.92. Tulosorganisointi murentaa työyhteisöä - tietotekniikka pahentaa tilannetta.

Vepsäläinen, K. 1989. Tietotekniikan perusopetus kehittämisen kohteena -tutkimusraportti. Tutkimusraportteja. Helsinki. Valtion painatuskeskus.

Vuorinen P. 1991. Miten onnistui ammatillisen keskiasteen koulunuudistuksen toimeenpano (muut tekijät Ekola Jorma, Kämäräinen Pekka). Teoksessa Ammatillisen koulutuksen uudistaminen 1980-luvulla. Tutkimuksia ja selosteita n:o 30/1991. Helsinki. VAPK-kustannus.

Zuboff, S. 1990. Viisaan koneen aikakausi - Uusi tietotekniikka ja yritystoiminta. Alkuteos "In the Age of the Smart Machine - The Future of Work and Power". Keuruu. Otava. 